\title{
Bearing Capacity of Strip Foundation on Soft Soil Reinforced with Stone Columns Using Method of Slices
}

\author{
M. Khalifa ${ }^{1(\bowtie)}$, M. Etezad ${ }^{2}$, A. Hanna ${ }^{1}$, and M. Sabry ${ }^{3}$ \\ 1 Department of Building, Civil and Environmental Engineering, \\ Concordia University, 1455 De Maisonneuve Blvd. W. Montréal, \\ Québec, Canada \\ ${ }^{2}$ Golder Associates Ltd., 6925 Century Avenue, \\ Suite \#100, Mississauga, ON L5N 7K2, Canada \\ ${ }^{3}$ Bechtel Corporation, 12011 Sunset Hills Road, \\ Suit 110, Reston, VA 20190, USA
}

\begin{abstract}
Stone columns are recognized as an environmently-friendly and cost-effective ground improvement technique. Stone columns are used in soft soil to increase the bearing capacity, reduce the settlement, increase the rate of settlement and reduce the liquefaction potential of the ground.

This paper presents an analytical model utilizing the method of slices to predict the ultimate bearing capacity of the soil reinforced with a group of stone columns. The soil within the failure zone was divided into slices and the limit equilibrium technique was adopted to perform the analysis. Shear forces and passive earth pressure on the boundaries of each slice were determined. By utilizing a circular failure plane, the minimum inter-slice force coefficients were determined.

The analysis was carried out using the Morgenstern-Price method to estimate the failure surface together with the bearing capacity of the reinforced ground. The failure surface was determined by trial and error to estimate the minimum factor of safety. The ultimate bearing capacity was defined by increasing the foundation load until the factor of safety of one was obtained. Results of the present theory were compared with those available in the literature, where a good agreement between the two was noted.
\end{abstract}

\section{Introduction}

Stone columns technique is a ground improvement method widely used over the past decades. Stone columns are stiffer and have higher shearing resistance than the native soft cohesive soil. This results in an increase of the soil bearing capacity and reduce in the corresponding settlement (Etezad et al. (2015); Mitchell et al. (1985); Muir Wood et al. (2000); Priebe (1995)). Furthermore, stone columns have higher permeability than the native surrounding soil, which leads to reduction of the drainage path and accordingly reduces the time required to complete the consolidation settlement (McKelvey et al. (2004)). 
Unit cell concept was one of the first methods used to estimate the bearing capacity of the ground reinforced with stone columns. The bulging mode of failure was used to model this process. Accordingly, the bearing capacity of a single stone column was predicted by estimating the horizontal capacity of the clay soil around the pile. In this method, the capacity of the group is the total capacities of the individual columns. Hughes and Withers (1974) used elastic-plastic theory developed by Gibson and Anderson (1961) to calculate the maximum vertical stress that can be carried by a single stone column due to bulging failure. Similar approach has also been used by Balaam and Booker (1981).

$\mathrm{Hu}$ (1995) performed laboratory tests on a group of end bearing and floating stone columns. Shear and punching mode of failure were reported in this study. He concluded that the collapse pattern for soil mass reinforced by stone columns changes from general shear failure mechanism to punching shear based on the stone column's length. The group interaction reported by Hu (1995) was confirmed by the numerical analysis carried out by Lee and Pande (1998); Muir Wood et al. (2000).

Priebe (1995) reported two methods to estimate the bearing capacity of a footing on the group of stone columns based on the general shear failure and the equivalent homogeneous composite. In the first approach, the weighted average values of the friction angle and the cohesion were calculated along the failure plane, and the bearing capacity was estimated using theories for homogeneous soils. In the second approach, a larger footing width was assumed, and the bearing capacity was determined using the new footing width and the shear properties of the unreinforced soil. (Lee et al. 1998) introduced the concept of composite properties of the reinforced soil. They used finite element technique to estimate the bearing capacity and settlement of the reinforced soil. Bouassida et al. (2009) presented design charts to determine the ultimate bearing capacity of a group of floating stone columns. In their study, the friction between the footing and the soil was neglected as well as the distribution of stone columns.

An analytical model was developed by Etezad et al. (2015) using limit equilibrium method and equivalent soil properties under the footing to calculate the bearing capacity of a rigid footing placed on the ground reinforced with stone columns. The method utilize the general shear failure and slip surface, which was deduced from the results of the numerical model of Hanna et al. (2013).

Many of the theories developed to predict the bearing capacity utilize the theory for homogeneous soil as a simplified assumption. In the present paper, the method of slices was adopted to estimate the bearing capacity of strip footing on a compacted inhomogeneous soil. Terashi et al. (1991) conducted a series of centrifuge tests and full-scale tests to estimate the bearing capacity of the improved ground by compacted sand piles. The experimental results agreed well with the bearing capacity calculated using a circular type of slip surface. Morgenstern-Price method was utilized in this study to calculate the bearing capacity of a footing rests on clay soil reinforced with stone columns. 


\section{Bearing Capacity Calculations Based on Slip Circle}

A 2-D model made of soft clay reinforced with stone columns was developed. The ground was loaded with a uniform pressure to simulate the case of strip footing. The failure zone was divided into 50 slides and the forces acting on each slide are shown in Fig. 1. The limit equilibrium method by Morgenstern et al. (1965) method was used in the computer program SIDE V-6.020, developed by Rocscience (2012), to calculate the minimum factor of safety of the circular slip surface (Fig. 2). The analysis was also check with the Bishop's Simplified method for comparison (Bishop 1955). The footing was loaded to the ultimate capacity in the form of uniform pressure applied on the ground surface.

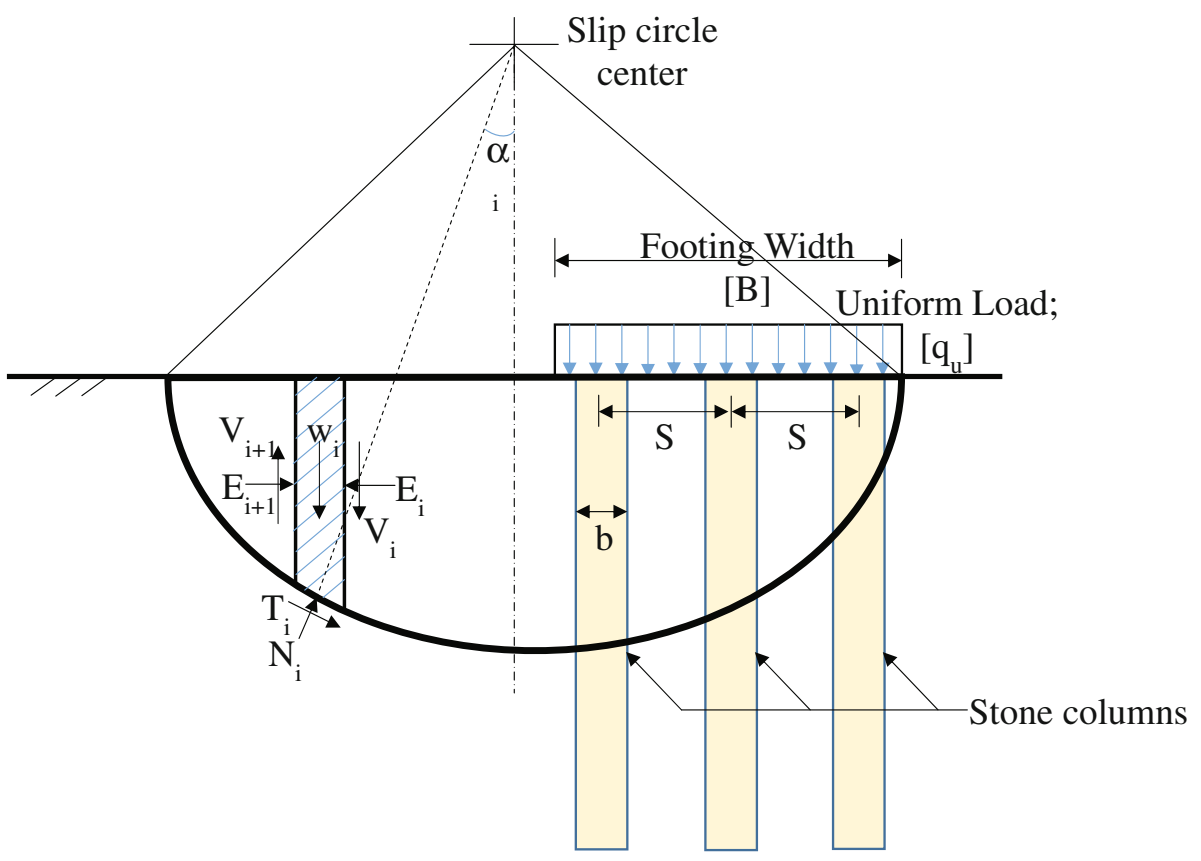

Fig. 1. Forces acting on a slide in the slip circle

\subsection{Validation}

The results obtained from the present analysis was compared with the laboratory and numerical results available in the literature (Hanna et al. (2013); Hu (1995); McKelvey et al. (2004)). Table 1 presents these comparison, where a good agreement can be noted. This further validate the methods of Morgenstern-Price and the Bishop's Simplified method of slices as viable techniques to estimate the bearing capacity of clay soil reinforced by a group of stone columns. However, Bishop's Simplified method generally overestimates the factor of safety as compared to Morgenstern-Price method (Turnbull et al. 1967). Nevertheless, both approaches underestimate the bearing capacity of the reinforced soil. 


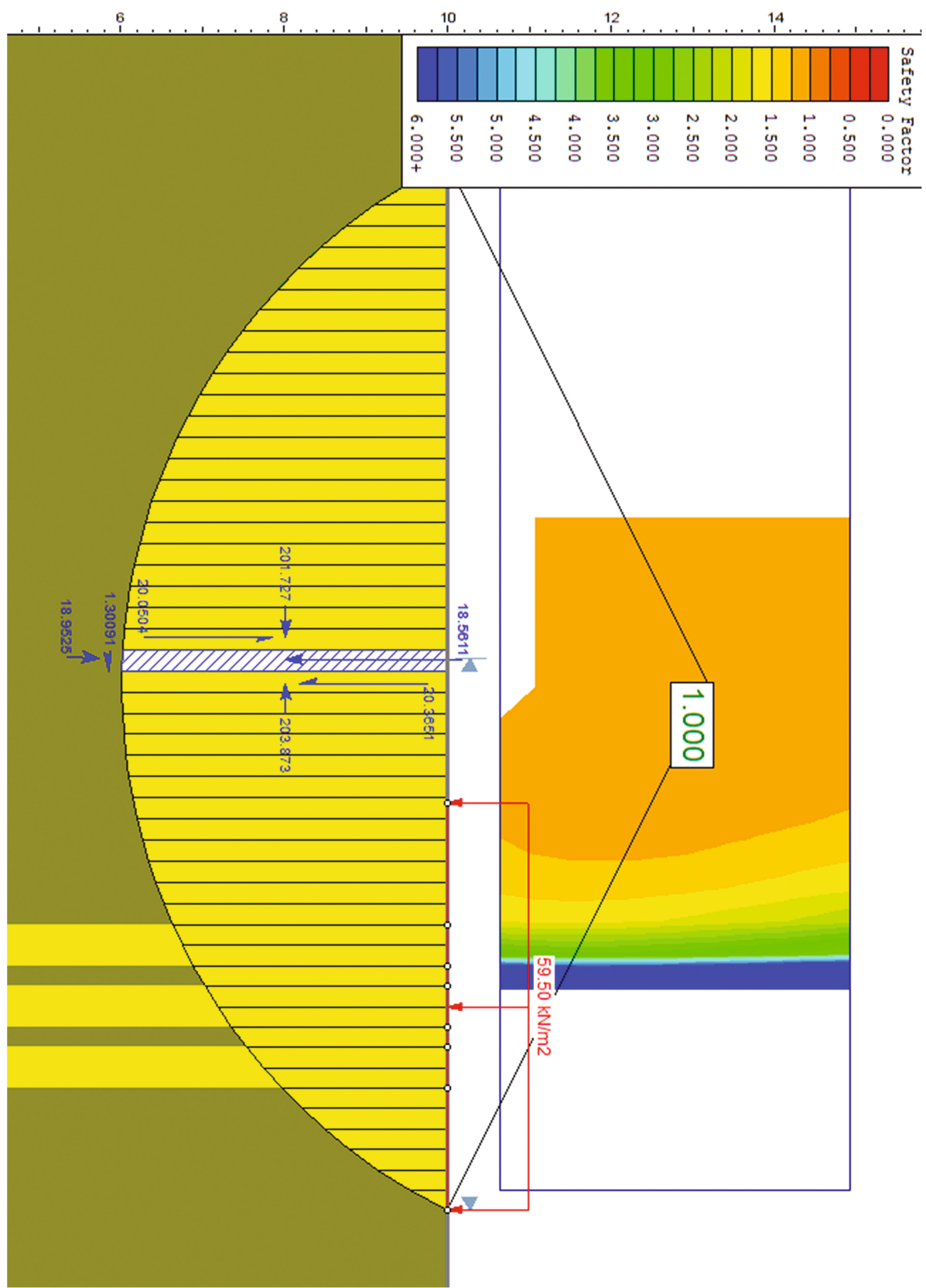

Fig. 2. An example of the bearing capacity calculation using slip circle method 


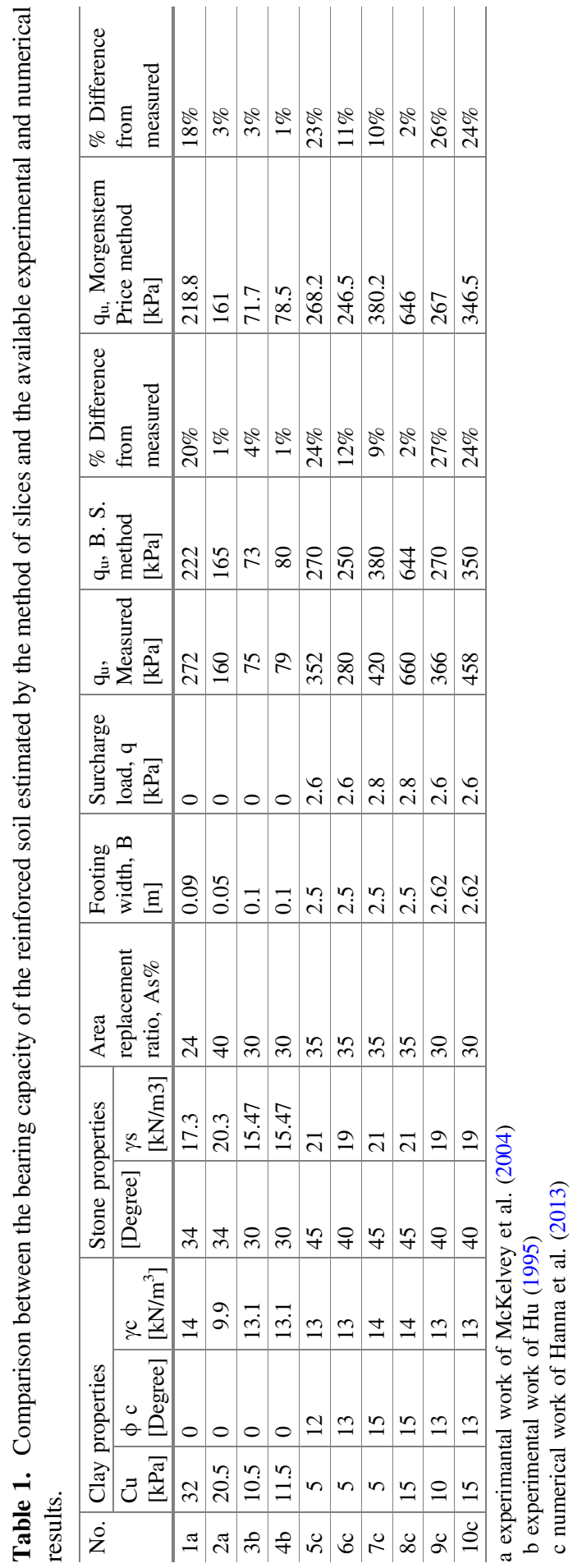




\subsection{Parametric Study}

In this study, the results are presented in the form of improvement ratio (IR), which is defined as the ratio of the capacity of improved soil to the capacity of the unimproved soil. In this analysis, the effect of the stone columns spacing to diameter ratio (S/D), and the number of stone column rows $(\mathrm{N})$ on the bearing capacity at a given replacement ratio (As \%) was performed. Each row of the stone columns was assumed as a trench with a width (b) and the spacing between trenches was considered the same as the spacing between columns as shown in Fig. 3. The trench width was calculated using Eq. 1. In this case, the replacement ratio (As) was calculated using Eq. 2. The ratio of $\mathrm{S} / \mathrm{D}$ was examined in the range of 1 to 3.0 as given in Table 2 .

$$
\begin{gathered}
b=\frac{\pi \times D^{2}}{4 \times S} \\
A_{s}=\frac{N \times b}{B}=\frac{N \times \pi \times D^{2}}{4 \times S \times B}
\end{gathered}
$$

Where,

$\mathrm{N}$ is the number of stone columns rows, $\mathrm{b}$ is the trench width, $\mathrm{B}$ is footing width, $\mathrm{D}$ is stone column diameter, and $\mathrm{S}$ is the spacing between stone columns.

Moreover, this method was also used to determine the effect of the undrained strength of the clay soil $(\mathrm{Cu})$, and the replacement ratio (As \%). In this analysis, the replacement ratio ranged from $10 \%$ to $30 \%$ which widely used in practice (Hanna et al. (2013); Hu (1995)). The range of the other parameters believed to govern the bearing capacity are presented in Table 3.

The effect of the column arrangement on the bearing capacity was also investigated. Figure 4 presents the spacing/ diameter ratio of stone columns versus replacement ratios, assuming all other parameters are constant. It can be noted that the bearing capacity increases with the increase of the replacement ratio. Also. It can be noted that the spacing between stone columns slightly influences on the improvement ratio. For low replacement ratio $(<10 \%)$, the improvement ratio is almost constant, which agreed well with Castro (2014) observation. However, the improvement ratio reduces with the increase of the columns spacing ratio; for higher replacement ratio (20\%, and $30 \%)$, which confirm that for small spacing between columns, the lateral support from the surrounding soil increases and accordingly, will show significant improvement.

Regarding the effect of the clay shearing resistance, it is noticeable that the improvement ratio reduces with the increase of shear strength of clay soil $(\mathrm{Cu})$ for the same spacing/ diameter ratio as shown in Fig. 5. Contrary, the improvement ratio raised by the increase of the stone columns shearing resistance angle $(\phi)$ as shown in Fig. 6.

The influence of stone columns number under the footing has been also investigated. In this analysis, the columns number varied from $\mathrm{N}=1$ to $\mathrm{N}=4$. The columns diameter ranged from $0.3 \mathrm{~m}$ to $1.6 \mathrm{~m}$, which covers the maximum and minimum ranges that may be used in practice. Figure 7 presents the effect of the stone columns number on the bearing capacity, and it can be noted that there is no remarkable change 




Front view

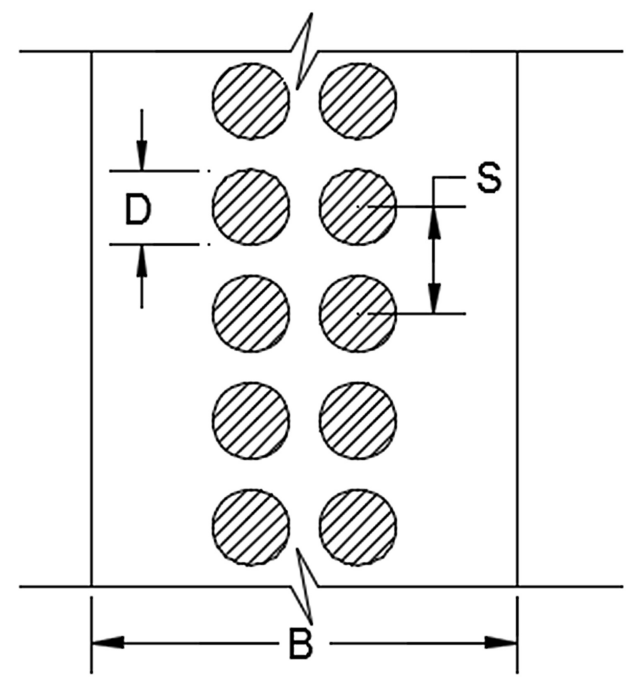

Top view

Fig. 3. Stone columns arrangement 
Table 2. Range of stone columns dimensions used in parametric study

\begin{tabular}{|c|c|c|c|c|c|}
\hline $\begin{array}{l}\text { Area replacement } \\
\text { ratio, As \% }\end{array}$ & $\begin{array}{l}\text { No. of } \\
\text { columns, N }\end{array}$ & $\begin{array}{l}\text { Column } \\
\text { diameter, } \\
\mathrm{D}[\mathrm{m}]\end{array}$ & $\begin{array}{l}\text { Column } \\
\text { spacing, } \\
\mathrm{S}[\mathrm{m}]\end{array}$ & $\begin{array}{l}\text { Spacing/Diameter } \\
\text { ratio, } \mathrm{S} / \mathrm{D}\end{array}$ & $\begin{array}{l}\text { Trench } \\
\text { width } \\
\mathrm{b}[\mathrm{m}]\end{array}$ \\
\hline \multirow[t]{7}{*}{$10 \%$} & 1 & 0.70 & 0.70 & 1.00 & 0.50 \\
\hline & 2 & 0.35 & 0.38 & \begin{tabular}{|l|l}
1.09 \\
\end{tabular} & 0.25 \\
\hline & 2 & 0.40 & 0.50 & 1.25 & 0.25 \\
\hline & 2 & 0.45 & 0.63 & 1.40 & 0.25 \\
\hline & 2 & 0.49 & 0.75 & 1.53 & 0.25 \\
\hline & 2 & 0.63 & 1.25 & 1.98 & 0.25 \\
\hline & 2 & 0.89 & 2.50 & 2.80 & 0.25 \\
\hline \multirow[t]{13}{*}{$20 \%$} & 1 & 1.30 & 1.30 & 1.00 & 1.00 \\
\hline & 2 & 0.69 & 0.75 & \begin{tabular}{|l|l}
1.09 \\
\end{tabular} & 0.50 \\
\hline & 2 & 0.80 & 1.00 & 1.25 & 0.50 \\
\hline & 2 & 0.89 & 1.25 & 1.40 & 0.50 \\
\hline & 2 & 0.98 & 1.50 & 1.53 & 0.50 \\
\hline & 2 & 1.26 & 2.50 & 1.98 & 0.50 \\
\hline & 2 & 1.69 & 4.50 & 2.66 & 0.50 \\
\hline & 3 & 0.46 & 0.50 & 1.09 & 0.33 \\
\hline & 3 & 0.53 & 0.67 & 1.25 & 0.33 \\
\hline & 3 & 0.59 & 0.83 & 1.40 & 0.33 \\
\hline & 3 & 0.65 & 1.00 & 1.53 & 0.33 \\
\hline & 3 & 0.84 & 1.67 & 1.98 & 0.33 \\
\hline & 3 & 1.00 & 2.33 & 2.34 & 0.33 \\
\hline \multirow[t]{16}{*}{$30 \%$} & 1 & 2.10 & 2.10 & 1.00 & 1.50 \\
\hline & 2 & 1.04 & 1.13 & 1.09 & 0.75 \\
\hline & 2 & 1.20 & 1.50 & 1.25 & 0.75 \\
\hline & 2 & 1.34 & 1.88 & 1.40 & 0.75 \\
\hline & 2 & 1.47 & 2.25 & 1.53 & 0.75 \\
\hline & 2 & 1.89 & 3.75 & 1.98 & 0.75 \\
\hline & 3 & 0.69 & 0.75 & 1.09 & 0.50 \\
\hline & 3 & 0.80 & 1.00 & 1.25 & 0.50 \\
\hline & 3 & 0.89 & 1.25 & 1.40 & 0.50 \\
\hline & 3 & 0.98 & 1.50 & 1.53 & 0.50 \\
\hline & 3 & 1.13 & 2.00 & 1.77 & 0.50 \\
\hline & 4 & 0.52 & 0.56 & 1.09 & 0.38 \\
\hline & 4 & 0.60 & 0.75 & 1.25 & 0.38 \\
\hline & 4 & 0.67 & 0.94 & 1.40 & 0.38 \\
\hline & 4 & 0.73 & 1.13 & 1.53 & 0.38 \\
\hline & 4 & 0.85 & 1.50 & 1.77 & 0.38 \\
\hline
\end{tabular}



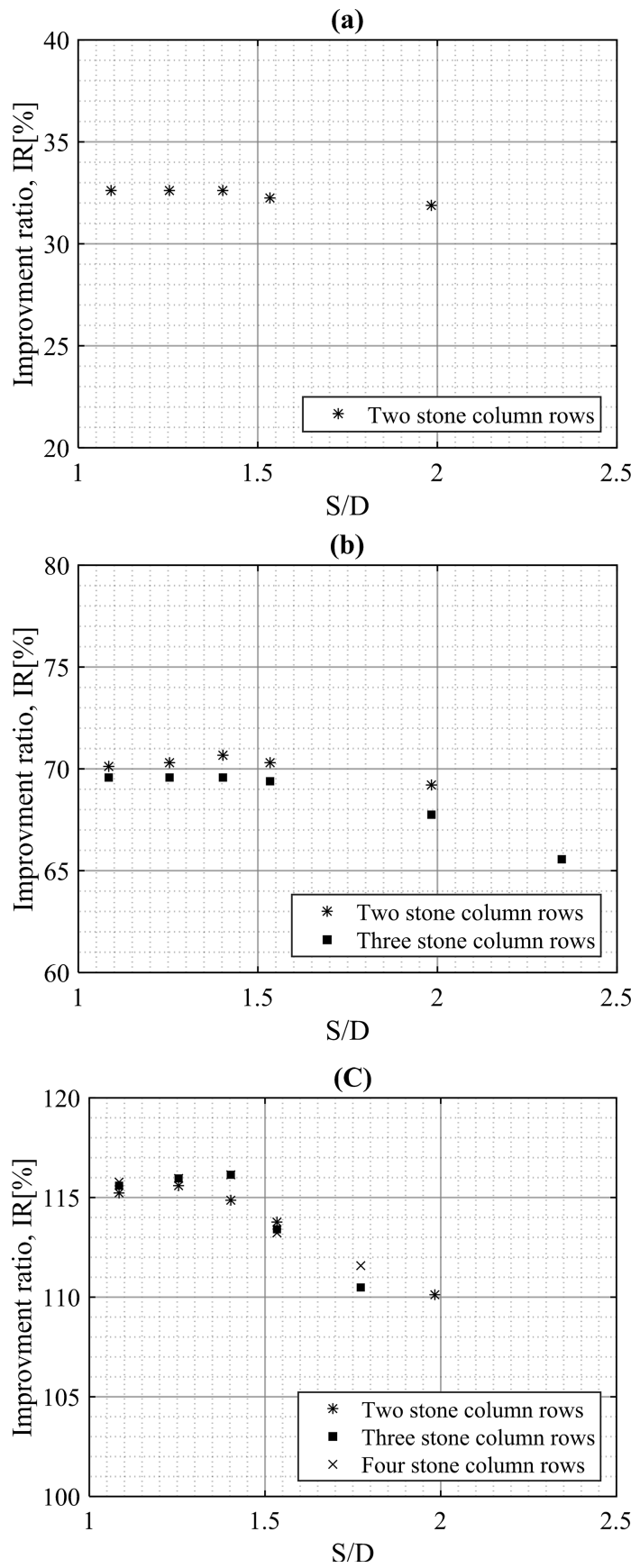

Fig. 4. Improvement ratio (IR) versus $\mathrm{S} / \mathrm{D}$ for different replacement area, $\mathrm{Cu}=5 \mathrm{kPa}, \Phi=35^{\circ}$ : (a) As $=10 \%$; (b) $\mathrm{As}=20 \%$; (c) $\mathrm{As}=30 \%$ 
(a)

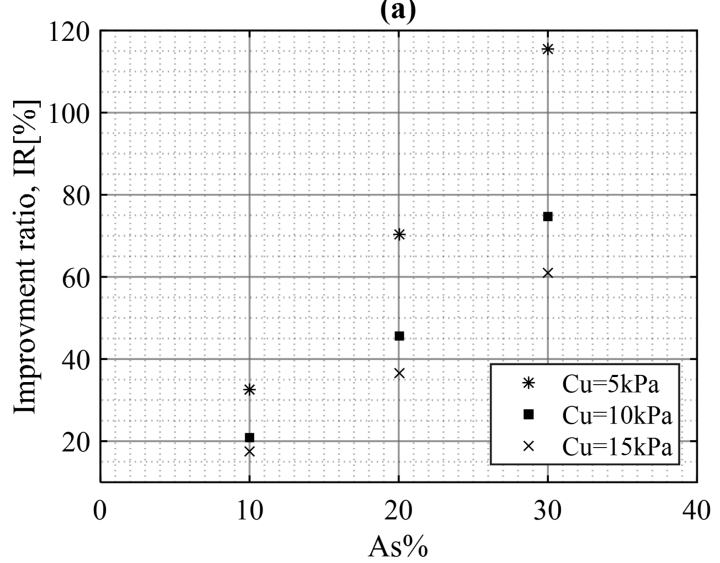

(b)

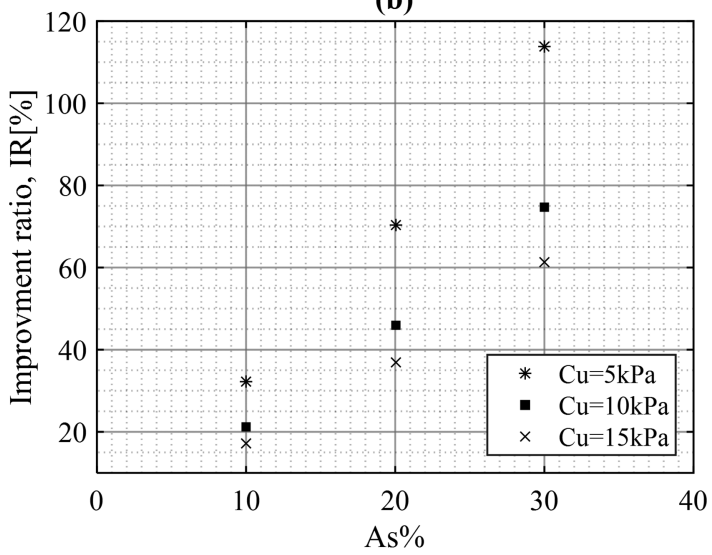

(c)

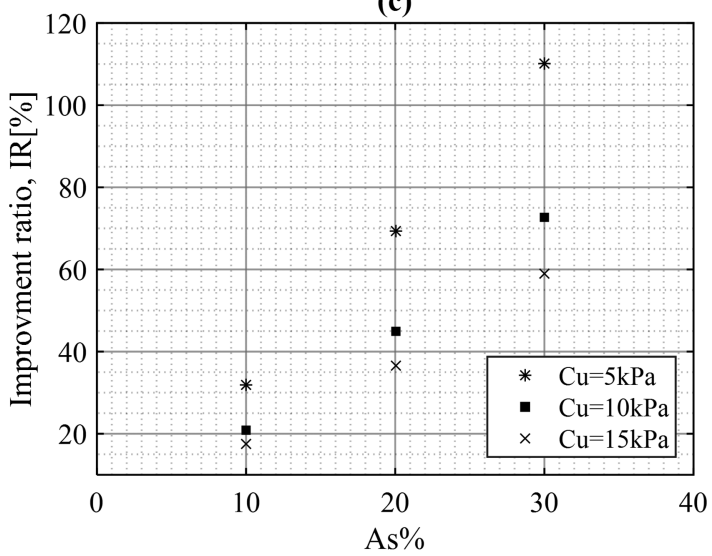

Fig. 5. Effect of shear resistance of clay on the improvement ratio for different replacement ratios, $\Phi=35^{\circ}$ : (a) $\mathrm{S} / \mathrm{D}=1.25$; (b) $\mathrm{S} / \mathrm{D}=1.50$; (c) $\mathrm{S} / \mathrm{D}=2.00$ 
Table 3. Range of parameter used in the parametric study

\begin{tabular}{l|l}
\hline Parameter & Range of value \\
\hline Cohesion of clay soil, $\mathrm{Cu}[\mathrm{kPa}]$ & 5,10, and 15 \\
\hline Unit weight of clay soil, $\gamma \mathrm{c}\left[\mathrm{kN} / \mathrm{m}^{3}\right]$ & 18 \\
\hline Angle of shear resistance of stone, $\phi_{\mathrm{s}}[$ Degree] & 35,38, and 40 \\
\hline Unit weight of stone, $\gamma \mathrm{s}\left[\mathrm{kN} / \mathrm{m}^{3}\right]$ & 20 \\
\hline Stone column diameter, $\mathrm{D}[\mathrm{m}]$ & $0.3-1.60$ \\
\hline Stone column diameter to spacing ratio & $1.00-2.50$ \\
\hline Replacement area, As $[\%]$ & 10,20, and 30 \\
\hline Footing width, B $[\mathrm{m}]$ & 5 \\
\hline
\end{tabular}

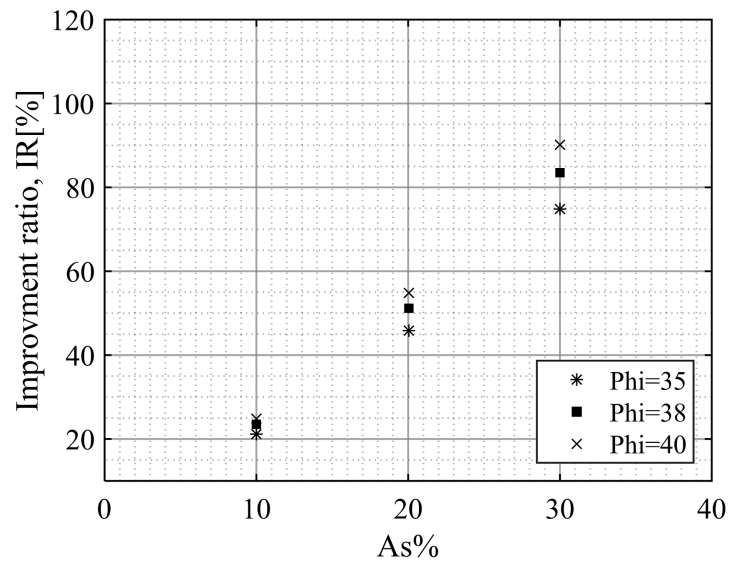

Fig. 6. Effect of shear resistance of stone on the improvement ratio for different replacement ratios, $\mathrm{Cu}=10 \mathrm{kPa} ; \mathrm{S} / \mathrm{D}=1.50$

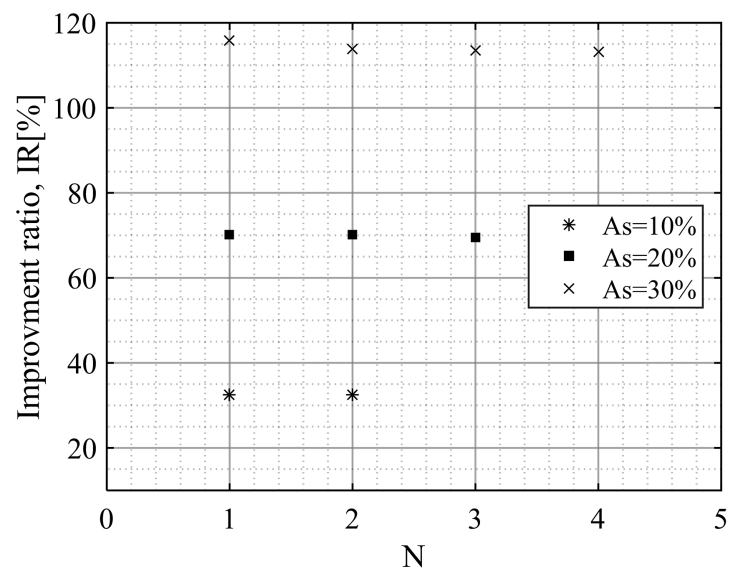

Fig. 7. The relation between number of stone column rows versus the improvement ratio, at $\mathrm{S} / \mathrm{D}=1.5, \mathrm{Cu}=5 \mathrm{kPa}, \Phi=35^{\circ}$ 
in the improvement ratio particularly for low replacement ratio $(<10 \%)$. However, there is a slight reduction in the improvement ratio for higher values of replacement ratio $(30 \%)$. For a large number of stone columns, a small diameter was used to keep the replacement ratio constant. By reducing the column's diameter more load will be transferred to the clay soil (less strength material), which lead to the reduction in the improvement ratio (Black et al. (2007); Hanna et al. (2013))

\section{Conclusions}

Morgenstern-Price method of slices was used to calculate the bearing capacity of a soft clay reinforced with stone columns. The theory developed compared well with the available results in the literature. Parametric study was conducted on the parameters believed to govern the behavior of this system. The following was concluded:

1- Morgenstern-Price method of slices was successfully used to estimate the bearing capacity of reinforced clay soil.

2- (IR) significantly increases with the increrase of the replacement ratio.

3- (IR) reduces due to the increase of the spacing/ diameter ratio (S/D)

4- Based on the results of the present study, in order to optimize the benefit of the use of reinforced soft clay with stone columns is to use a ratio of columns spacing to columns diameter (S/D) equal to 1.5

5- For the same stone columns arrangement and shear resistance (diameter, spacing) the improvement ratio (IR) increases with a decrease of the shear strength of surrounding clay. However, the ultimate bearing capacity of the system is significantly increased due to the increase of the shear strength of the clay soil as well as the stone. Furthermore, the improvement ratio (IR) increases with the increase of the stone columns shearing resistance angle.

Acknowledgments. The financial support received from Concordia University is acknowledged.

\section{References}

Balaam, N., Booker, J.R.: Analysis of rigid rafts supported by granular piles. Int. J. Numer. Anal. Meth. Geomech. 5(4), 379-403 (1981)

Bishop, A.W.: The use of the slip circle in the stability analysis of slopes. Geotechnique 5(1), $7-$ 17 (1955)

Black, J., Sivakumar, V., McKinley, J.: Performance of clay samples reinforced with vertical granular columns. Can. Geotech. J. 44(1), 89-95 (2007)

Bouassida, M., Jellali, B., Porbaha, A.: Limit analysis of rigid foundations on floating columns. Int. J. Geomech. 9(3), 89-101 (2009)

Castro, J.: Numerical modelling of stone columns beneath a rigid footing. Comput. Geotech. 60, $77-87$ (2014) 
Etezad, M., Hanna, A., Ayadat, T.: Bearing capacity of a group of stone columns in soft soil. Int. J. Geomech. 15(2) (2015)

Gibson, R., Anderson, W.: In situ measurement of soil properties with the pressuremeter. Civil Eng. Public Works Rev. 56(658), 615-618 (1961)

Hanna, A., Etezad, M., Ayadat, T.: Mode of failure of a group of stone columns in soft soil. Int. J. Geomech. 13(1), 87-96 (2013)

$\mathrm{Hu}$, W.: Physical modelling of group behaviour of stone column foundation. (Ph.D. dissertation), University of Glasgow, UK (1995)

Hughes, J., Withers, N.: Reinforcing of soft cohesive soils with stone columns. Ground Eng. 7 (3), 42-49 (1974)

Lee, J.S., Pande, G.N.: Analysis of stone-column reinforced foundations. Int. J. Numer. Anal. Meth. Geomech. 22(12), 1001-1020 (1998)

McKelvey, D., Sivakumar, V., Bell, A., Graham, J.: A Laboratory Model Study of the Performance of Vibro Stone Columns in Soft Clay. J. Geotech. Eng. 152, 1-13 (2004)

Mitchell, J.K., Huber, T.R.: Performance of a stone column foundation. J. Geotech. Eng. 111(2), 205-223 (1985)

Morgenstern, N., Price, V.E.: The analysis of the stability of general slip surfaces. Geotechnique 15(1), 79-93 (1965)

Muir Wood, D., Hu, W., Nash, D.: Group effects in stone column foundations: model tests. Geotechnique 50(6), 689-698 (2000)

Priebe, H.J.: The design of vibro replacement. Ground Eng. 28(10), 31 (1995)

Rocscience: SLIDE 6.0 -2D Slope Stability Analysis for Soil and Rock Slopes. Rocscience Inc. (2012)

Terashi, M., Kitazume, M., Minagawa, S.: Bearing capacity of improved ground by sand compaction piles. In: Deep Foundation Improvements: Design, Construction, and Testing. ASTM International (1991)

Turnbull, W. J., Hvorslev, M.J.: Special problems in slope stability. J. Soil Mech. Found. Div. (1967) 